- http://roncea.ro/2011/09/19/rosia-montana-si-salvatorii-ei-mirceatoma-si-liviu-mihaiu-salarii-de-milioane-de-euro-capcanate-cuajutorul-idiotilor-utili-care-lupta-pentru-ecologie-si-patrimoniulnational/

- $\quad$ http://www.danbadea.net/2014/01/24/sobolanul-voiculescu-si-puriciicrescuti-in-blana-lui-ce-au-transmis-ciuma-bubonica-in-presaromaneasca/

- http://roncea.ro/2011/08/14/fan-fest-in-delir-fotografie-exclusiva-dela-fata-locului-cu-george-soros-mircea-toma-si-renate-webersalvatorii-rosiei-montane/

- http://roncea.ro/2011/09/02/cianura-ucide-dar-si-prostia-ucideromania-societatea-civila-bolsevica-si-apologetii-crestini/

- http://www.cdep.ro/proiecte/2011/100/10/8/em118.pdf

- http://www.cdep.ro/proiecte/2011/100/10/8/pvg118.pdf

- http://pettycluj.blogspot.ro/2010/07/credinta-tarilor-candidate-ue-darcare.html

- http://saccsiv.wordpress.com/2009/08/27/indemn-unesco-copiii-vorinvata-despre-masturbare-la-5-ani-si-despre-avort-la-12-ani/

- http://www.libertatea.ro/detalii/articol/copiii-care-primesc-educatiesexuala-isi-pierd-virginitatea-mai-devreme-274805.html

- http://saccsiv.wordpress.com/category/sex-oral/Filmul "Living and Growing" promoveazadesfranarea, perversiunile, homosexualitateasianticonceptionaleleelevilor de 8 ani din scolile britanice

- http://www.hotnews.ro/stiri-international-5952156-elevii-din-mareabritanie-sunt-indemnati-aiba-orgasm.htm

- http://saccsiv.wordpress.com/2009/11/18/campanie-pro-masturbare-inspania-placerea-sta-in-mainile-tale/

- http://invataturicrestine1.blogspot.ro/2012/10/pericolele-modului-deeducatie-sexuala.html 


\section{BISERICA ŞI TINERETUL. PROBLEME MORALE ALE TINERILOR DE AZI \\ ŞI SOLUȚIILE LOR DIN PERSPECTIVĂ CREŞTINĂ}

\section{Simion Todoran*}

Abstract: It is widely known that humanity is going through a period of rapid transformation, of amazing progress. The progress of science and technique is the most obvious, and it influences every sector of human life. Science goes deeper and deeper into the knowledge of the world by discovering new laws, unexpected new energies. With the help of science, the technique places tools at man's disposal, which help him master more and more the forces of nature; it places those forces in the service of the humanity. Our time is the time of the young. An old world crushes, while a new one is searching for its forms of life. Its pulse is beating in the veins of the young. It beats faster because of the anxiety, uncertainty, and the unknown. Undoubtedly, there is a gap between the old generation and the new one. The anxiety of the old generation transforms itself into sighs for the ending world. The restlessness of the new generation is represented by the hopes for the coming world. That is why the young represent today's universal preoccupation. The states where social life searches more thoroughly its new location made this preoccupation their main issue. Obviously, nowadays' children do not resemble the children that lived 40-50 years ago. If we were to establish on which mystery road the transformation had begun under our eyes, and how we the parents are and still remain unliable to our children, we would be too much into an insecure area, but which is suddenly enlightened by the Holy Scriptures by the indisputable sentence: "The fathers have eaten a sour grape and the children's teeth are set on edge".

Keywords: Church, word, young, education, generation, social life, God, children, science.

\section{Introducere}

E un fapt, recunoscut de toţi că omenirea se află într-o epocă de rapidă transformare, de progrese uluitoare. Evidente sunt întâi progresele ştiinţei şi tehnicii, care îşi pun pecetea asupra tuturor sectoarelor vieţii omeneşti. Ştiinţa pătrunde tot mai adânc în cunoaşterea lumii, descoperind noi legi, noi energii, nebănuite, tehnica

\footnotetext{
* PhD Professor, Faculty of Orthodox Theology, at University "1 Decembrie 1918" Alba Iulia, Romania.
} 
pe baza ştiinţei, pune la dispoziţia omului unelte, care îl ajută să stăpânească tot mai deplin forţele naturii, să pună în slujba sa aceste forţe ${ }^{1}$. Vremea noastră e vreme atineretului. $\mathrm{O}$ lume veche se dărâmă, o lume nouă își caută formele de viaţă. Pulsul ei zvâcnește în venele tineretului. Puls iuţit de nelinişte, întretăiat de nesiguranţe, biciuit de enigme. Intre generaţia veche şi generaţia nouă există, incontestabil, un hiatus. Nelinişteageneraţiei vechi se transformă în suspine după lumea care amurgeşte; zbuciumul generaţiei noi sunt nădejdi aruncate spre lumea care vine. De aceea, tineretul e azi preocuparea universală. Statele în care viaţa socială îşi caută mai accentuat noile forme de aşezare şi-au făcut din această preocupare de tineret problema principala ${ }^{2}$. Copiii de azi, este clar, nu mai seamănă cu noi, copiii de acum 40-50 de ani. Dacă ar fi să căutăm să stabilim pe ce cărări tainice a pornit prefacerea de sub ochii noştri, şi cum noi, părinţii, suntem şi rămânem totuşi nesolidari cu copii noştri, ar fi să rămânem prea mult într-un domeniu nesigur, pe care însă Sfânta Scriptură îl luminează deodată cu sentinţa inatacabilă: „Părinţii au mâncat aguridă şi s-au sterpezit dinţii copiilor".

Trebuie să recunoaştem că marele păcat al generaţiei noastre, adică credinţa aproape exclusivă în cele ce se văd şi se pot pipăi, a trecut în sângele copiilor şi s-a înrăutăţit. Noi, cei bătrâni, eram ispitiţi de ideea că lumea aceasta trebuie cultivată numai pentru ea. Copiii noştri sunt furioşi, încredinţaţi că lumea aceasta trebuie cucerită cu orice preț şi cu orice primejdie. Putem spune, pe scurt, că toată răutatea şi dezordinea date pe faţă de actuala tânără generaţie, provin din jalnicul materialism, mai mult sau mai puţin, contemporan, agravat de conflictele dintre popoare ${ }^{3}$.

Lupta pentru noile tipare de viaţă nu are însă un caracter politic şi social. Tendinţa ei este să consolideze noile forme într-o concepţie integrală de existenţă. Din Evul Mediu ideea metafizică n-a fost atât de

\footnotetext{
${ }^{1}$ Nicolae Mladin, Studii de Teologie Morală, Sibiu, 1969, 153.

2 Nechifor Crainic, Tineretul şi creştinismul, în vol „Biserica şi problemele actuale", Bucureşti, 1933, p. 107.

3 Gala Galaction, Copiii noştri, în vol. „Probleme actuale în Biserică şi Stat”, Bucureşti, 1935, p. 53-54
} 


\section{$15^{\text {th }}$ International Symposium on Science, Theology and Arts}

amestecată în actualitatea imediată. Dacă sub acest raport, epoca liberalismului se caracterizează printr-o indiferenţă metafizică ce îngăduia calea mediocrităţii, tendinţele dominante ale vremii de azi merg până la extrem; până la suprema afirmaţie sau până la suprema negaţie. Creştinismul şi ateismul sunt punctele culminante, care solicită psihologia zbuciumată a generaţiei tinere. Am putea să definim spiritul nou al vremii prin oroarea faţă de dimensiunile mijlocii şi prin pasiunea exclusivistă a liniilor infinite: fie linia orizontală, de platitudine uniformă, a comunismului ateist (care trăieşte, încă, în multe conştiinţe), fie verticala infinită a ierarhiilor cimentate de spiritualismul creştin. „Aurea mediocritas” a lui Horaţiu e o formulă de viaţă calmă ce nu-şi găseşte locul în gigantica încordare de forţe a epocii noastre ${ }^{4}$.

Problema „Bisericii şi a tineretului” nu e azi o problemă de cateheză şi pastorală, în care Biserica să aibă iniţiativa, ci e o problemă de atitudine impusă tineretului de spiritul vremii ${ }^{5}$.

Fiecare epocă creştină a avut luptele, biruinţele şi înfrângerile ei. Armele de luptă, argumentele apologetice, metodele defensive şi ofensive, se deosebesc şi s-au deosebit de la epocă la epocă. Biserica nu poate sta pasivă în mijlocul acestor transformări. Deşi dogmele sunt aceleaşi, cultul este acelaşi, disciplina bisericească este aceeaşi, totuşi viaţa bisericească e pe cale de înnoire. Adevărul creştin este veşnic, dar el trebuie să satisfacă setea după o viaţă avansată a tuturor oamenilor, a credincioşilor din vremea noastră. Fiind veşnic, adevărul creştin e mereu nou, e mereu contemporan, niciodată rămas în urmă, depăşit ${ }^{6}$. Pentru aceea cei ce reprezintă Biserica, trebuie să fie pătrunşi adânc de duhul lui Hristos - care e veşnic viu - şi de spiritul înnoitor al vremii. Iisus Hristos ne cheamă să colaborăm cu El, să colaborăm cu oamenii de pretutindeni, pentru o viaţă nouă în dragoste, dreptate şi pace.

Tineretul nostru românesc, în bătaia curentelor contradictorii ce ne vin , atât din Apusul Europei cât şi din sincretismul euro-asiatic sau trans-atlantic, se găseşte în situaţia de a lua „suasponte” o atitudinea

\footnotetext{
${ }^{4}$ N. Crainic, op. cit., p. 107-108.

${ }^{5}$ Ibidem.

${ }^{6}$ G. Galaction, op. cit., p. 54.
} 
sau alta faţă de creştinism. Bisericii îi rămâne sarcina să capteze şi să filtreze valurile afirmative ce-i năvălesc în prag sau să împrejmuiască valurile negative şi rebele ce-i bat în coastă ${ }^{7}$, spunea profetic N. Crainic acum aproape 70 de ani .

Este ştiut că, în educaţia omului, buna tradiţie şi ordinea severă sunt mult mai hotărâtoare şi mai bine făcătoare decât o cultură lipsită de sistem şi oferită fără verificări, fără nici o precauţiune ${ }^{8}$.

Noi vom considera raportul dintre Biserică şi tineret sub unghiul iniţiativei tineretului de a se apropia de Iisus Hristos.Aceasta nise pare trăsătura fundamentală a problemei ce ne preocupă aici.

Am scris această conferinţă cu gândul că înţelegând mai bine prezentul putem să sesizăm mai bine viitorul. Printre emisiunile de radio şi televiziune cele mai ascultate sunt buletinele meteorologice. Fiecare doreşte să-şi organizeze timpul, munca şi bucuriile sale în cele mai bune condiții. Fotografiile luate din satelit descoperă zonele înnourate, permiţând anunţarea timpului înnourat sau însorit, seceta sau ploaia. Tot astfel, din totdeauna, oamenii au căutat să-şi descopere viitorul, zilele propice pentru afaceri ${ }^{9}$.

\section{Tendințe de împărţire}

Se cunoaşte opoziţia dintre Est şi Vest, dintre Nord şi Sud, opoziţie, care,din diferite raţiuni astăzi este din ce în ce mai complexă. În anul 1900 populaţia albă reprezenta $30 \%$ din 1,65 miliarde de locuitori. Astăzi sunt $20 \%$ la 6 miliarde de oameni. În acest timp populaţia de culoare, de patru ori mai numeroasă, dispune de condiţii de viaţă, adesea, mediocre.

Se constată un declin demografic în ţările industriale şi o suprapopulare în ţările în curs de dezvoltare. Tendinţa tinerilor de a emigra în statele industrializate se loveşte de două obstacole : 1)

\footnotetext{
${ }^{7}$ N. Crainic, op. cit., p. 108.

${ }^{8}$ G.Galaction, op. cit., p. 54.

${ }^{9}$ Pierre Lanares, Faire face au desordre mondial, Trento, 1993, p. 11.
} 


\section{$15^{\text {th }}$ International Symposium on Science, Theology and Arts}

şomajul şi 2) calificarea necorespunzătoare, în timp ce industria cere muncitori calificaţi ${ }^{10}$.

Din punct de vedere politic se constată un eşec al modelelor politice. Capitalismul şi socialismul împărţeau populaţia globului . Capitalismul a servit Statul în a ignora legea cererii şi a ofertei; Socialismul a fost incapabil de a împlini speranţele promise.

Majoritatea a ajuns să fie contestată. Democraţia presupune ca minoritatea să se supună majorităţii. Din ce în ce mai mult, minorităţile ideologice (ecologice, economice, etnice, regionale, etc.), nu acceptă deciziile luate de majoritate, ducând la lupte, uneori, violente. În astfel de situaţii structurile puterii se văd puse în poziţia de a dispune de autoritatea $\operatorname{lor}^{11}$.

Se constată sfârşitul non-ingerinţei.Toate mijloacele de informare în masă ( presa, radioul televiziunea) ne permit să ştim ce se întâmplă în lume, cel puţin parţial. Opinia publică poate să oblige un guvern să intervină într-o problemă umanitară sau politică. În principiu suveranitatea naţională este intangibilă, dar războiul din Golf, cel din ex-Iugoslavia, intervenţia NATO în Iugoslavia etc., a suscitat o ingerință umanitară pe baza unui drept internaţional. Este greu de stabilit care sunt limitele unui astfel de drept.

Războiul pentru supremaţia economică a secolului 21 a început deja. Cea mai importantă inovaţie a timpului nostru va fi naşterea unui nou sistem de creare de averi, bazat nu pe forţa muşchilor, ci pe inteligenţă. Aceasta este de fapt apariţia economiei ştiinţei, ce a lansat economiile avansate într-o teribilă competiţie mondială.

Winston Chrchill a făcut odinioară această profeţie: „imperiile viitorului vor fi imperii ale spiritului”. Această profeţie s-a împlinit. Este ceea ce se întâmplă printr-o convergenţă a mutaţiilor din producţia propriu-zisă, compoziţia capitalului şi până la natura noii monezii de schimb. Aceste schimbări sunt pe cale să instaleze pe scară mondială un sistem revoluţionar de creare a bogăţiilor ${ }^{12}$.

\footnotetext{
${ }^{10}$ Ibidem, p. 21-22.

${ }^{11}$ A. Toffler, Les nouveaux pouvoirs, Paris, 1990, p. 475, 477.

${ }^{12}$ Ibidem, p. 205, 26, 27, 110.
} 
Tabloul acesta este completat de alte trei realităţi: declinul, tot mai accentuat al comunismului, imposibilitatea ţărilor în curs de dezvoltare de a se uni şi apariţia Japoniei şi a Europei ca rivale ale Statelor Unite. Aceasta este lupta ce se va da pentru dominarea secolului $21^{13}$.

Statele Unite posedă o capacitate de acţiune militară fără egal. Deficitul americanilor depinde de finanţarea Japoniei. În anul 1991 deficitul SUA era de 318 miliarde dolari ${ }^{14}$.

Europa, cu cei 320 milioane de locuitori dispune de un produs naţional brut echivalent cu cel al Statelor Unite şi 1 şi jumătate cu cel al Japoniei. Ţările care formează comunitatea economică europeană dețin $20 \%$ din comerţul mondial. Dar omogenitatea politică şi economică este departe de a fi realizată pentru a face faţă concurenţei ${ }^{15}$.

Din punct de vedere cultural societatea s-a individualizat. Un număr tot mai mare de oameni lucrează acasă. Creativitatea nu poate fi realizată decât de persoanele extrem de individualizate. Ideologia revoluţionară franceză l-a eliminat pe Dumnezeu din societate, deşi s-a structurat pe baza catolicismului.

Sfârşitul secolului 20, după Casanova, se va explica prin patru evenimente :

- biruinţa democraţiei asupra totalitarismului;

- miracolul japonez;

- renunţarea Chinei de a se prezenta drept model;

- renunţarea, de către URSS, la marxism- leninism ${ }^{16}$.

Regimul politic al României actuale, de peste 25 de ani, încercă să fie unul democratic, nu are o grijă deosebită pentru tineri. Biserica Ortodoxă, deşi Biserică majoritară, e privită mai mult dintr-un unghi

\footnotetext{
${ }^{13}$ Pierre Lanares, op. cit., p. 2

${ }^{14}$ Ibidem.

15 Ibidem; Japonia posedă o treime din bugetul militar al lumii. Este primul creditor al planetei. Este în fruntea tuturor domeniilor ştiinţei tehnologice şi spaţiale. Japonia acumulează, în fiecare an, un excedent de 200 miliarde de dolari, cu care achiziţionează mari trusturi, mai ales în Statele Unite. Vezi şi J. Attali, Lignes d'horizons, Paris, Fayard, 1990, p. 98.

${ }^{16}$ J.-C. Casanova, L'Expres,20 octobre, 1989.
} 


\section{$15^{\text {th }}$ International Symposium on Science, Theology and Arts}

festivist, decorativ. În realitate e un stat laic, indiferent din punct de vedere religios, gata oricând să socotească religia ca o simplă afacere particulară după cea mai bună regulă democratică şi să se simtă incomodat ori de câte ori religia se conturează ca forţă colectivă socială ${ }^{17}$. Statul nu vede în cultul organizat nici măcar o formă de disciplină socială şi de solidaritate morală, ci mai mult o sarcină bugetară la care e gata renunţe oricând ${ }^{18}$.

Aceeaşi indiferenţă oficială se observă faţă de tineret. În țările civilizate problema tineretului constituie o problemă vitală, România e aproape pe ultimul loc la acest capitol. $\mathrm{Nu}$ e tineret sub soare mai abandonat propriei său destin ca tineretul nostru românesc. Cine se preocupă de pregătirea acestui tineret pentru o epocă ce se apropie cu paşi uriaşi ? Nu se pun oare pentru el aceleaşi întrebări grele ca pentru tineretul de pretutindeni ? Nu stă şi el astăzi în faţa perspectivei tragice a şomajului ? Şomajul reprezintă nu numai lipsa mijloacelor pentru un trai decent ci şi o criză de identitate pentru cel ce continuă să se integreze în societate. De aici se ajunge la folosirea drogurilor, la corupţie şi prostituţie. Nu e şi el setos de o concepţie integrală de viaţă în care să-şi salveze sufletul din ruinele ce se îngrămădesc în jurul lui ?

Exodul tinerilor, o altă realitate crudă, acel flux migrator făcut din raţiuni politice şi economice, a devenit incontrolabil. După unele statistici neoficiale, din România au emigrat într-o perioadă de 3 ani peste 500.000 de mii de tineri cu studii superioare ! Ce pierdere imensă pentru un stat ! Câte lucruri, pentru care s-au pregătit în licee şi facultăţi, -pentru care s-au cheltuit bani şi multă energie, s-ar fi putut face ! Din țările Europei de Est emigrează cam 450.000 mii de persoane anual. Ce se va întâmpla cu cele 20 de milioane de emigranți din toate ţările lumii ? când încet,încet se închid graniţele.În anul 2015, situaţia grea din Siria, Iran, Irak şi din alte ţări din nordul Africii şi ale Orientului mai apropiat sau mai îndepărtat a ridicat probleme deosebite

${ }^{17}$ A se vedea reacţia durã a unei părţi a societăţii româneşti la afirmaţia I.P.S. Bartolomeu Anania, în legătură cu o posibilă implicare a Bisericii în „sfătuirea" celor ce cer ,consultanţă "în ceea ce priveşte opţiunea în noile alegeri. Reacţia s-a repetat şi cu ocazia altor alegeri ce s-au derulat până în anul 2015.

${ }^{18}$ De ani de zile se tot promite salarizarea integralã a pesonalului clerical. 
în rândul ţărilor din Europa în ceea ce priveşte o anumită convergenţă în rezolvarea pe termen mediu sau lung a acestor mari mutaţii umane, unde sunt implicaţi mai mulţi factori ca cel social, cultural, religios şi nu în ultimul rând cel economic.

Presa, cinematograful, radioul şi televiziunea, care sunt instrumentele cele mai de seamă ale unei sănătoase îndrumări, sunt astăzi în România cele mai periculoase mijloace ale dezagregării morale. Librăriile şi chioşcurile gem de reviste pornografice în care imaginea trupului gol se întrece cu textul celor mai abjecte apologii ale instinctelor inferioare. O literatură de prost gust dă un prestigiu pseudoştiinţific tuturor acestor aberaţii proferate în numele nudismului, al naturismului şi al eliberării de obsesiile sexuale ${ }^{19}$. Tolerându-le, statul se face complice la funesta operă de demoralizare a tineretului. În ordinea politică şi socială, pătura conducătoare nu oferă ca îndrumare decât cluburile de partid în care tineretul e momit pentru a fi schilodit sufleteşte după chipul şi asemănarea politicianismului, precum anume cerşetori de profesie fură copii şi le desfigurează trupurile mici ca să-i facă apţi pentru practicarea cerşitoriei.

Studenţii români sunt săraci. Copii de oameni care trăiesc din salarii mici, unii au părinţii şomeri, duc după ei sărăcia lucie de-acasă. În universităţi s-au constituit Asociaţia Studenţilor Creştini Ortodocşi Români (ASCOR).

Faptul că după decembrie 1989 Biserica Ortodoxă a fost ţinta unor atacuri extrem de violente, a determinat tineretul nostru să evolueze din ce în ce mai mult spre o stare de conştiinţă.

La toate acestea se adaugă un lucru nou : debandada şi jafurile din averea publică ale politicienilor ${ }^{20}$. Se nasc reacţii morale ale tinerilor (a se vedea reacţia tinerilor provocată de catastrofa de la Clubul Colectiv din Bucureşti, din oct.-nov. 2015). Se cunosc

${ }^{19}$ Ilie Moldovan, Darul sfânt al vieţii şi combaterea păcatelor împotriva acestuia, Bucureşti, 1997, p. 27.

${ }^{20}$ A se vedea cazurile notorii ale celor ce au "jefuit" bãncile, ale celor ce au dus la faliment, intenţionat, în limitele infractionalului, multe intreprinderi, cu mii de miliarde de lei. A se vedea spectacolul jalnic, văzut zilnic, la DNA, DICOT, sau la alte instituţii ale statului, cu cei pe care noi i-am ales să ne reprezinte interesele... 


\section{$15^{\text {th }}$ International Symposium on Science, Theology and Arts}

manifestările tinerilor, - şi ale vârstnicilor deopotrivă, din Piaţa Universităţii, din primăvara anului 1990. Se cunosc şi consecinţele : o mineriadă sângeroasă, populaţia şi, mai ales, intelectualitatea tânără din Bucureşti a fost maltratată, capii studenţilor duşi la închisoarea Jilava. Tinereţea lor prigonită pentru dreptate şi comprimată între pereţii închisorii nu află alt sprijin decât în Dumnezeu.

În atitudinea ei faţă de Biserică, generaţia tânără manifestă o altă înţelegere. Biserica e o putere vie şi actuală, o pârghie necesară a vieţii prezente. În ultima perioadă, din nefericire, se simte o manipulare a tinerilor şi nu numai a lor, împotriva Bisericii, în special a Bisericii Ortodoxe. Este foarte adevărat că s-au făcut şi unele greşeli de comunicare cu turma pe care o păstorim, greşeli pe care trebuie să ni le asumăm, dar a lovi în ,instituţia cea mai trainică şi mai sigură a poporului român”, aşa cum numea marele istoric Nicolae Iorga despre Biserica Ortodoxă, este mult prea mul şi nedrept.

Inima, a zis Pascal, îşi are raţiunile ei pe care raţiunea nu le cunoaşte. Să zicem în loc de inimă, viaţă - şi să repetăm adevărul profund al genialului gânditor că viaţa îşi are raţiunile misterioase pe care raţiunea nu le cunoaşte. Criza contemporană nu e numai economică, nu e numai financiară, nu e numai politică, nu e numai socială, nu e numai morală; ea e criză ontologică ce pune din nou problema originii vieţii şi deci a destinului omenesc.

Se vorbeşte mult despre ,educaţia simţurilor”, dar ne preocupăm prea mult de activitatea periferică a simţurilor. Trebuie să apelăm mai ales la voinţa de a vedea bine şi de a auzi bine, de a reţine bine ceea ce am văzut şi am auzit. Să încercăm să dăm toată atenţia culturii energiilor morale, - şi făcând aceasta, vom vedea că, prin chiar natura ei, cura morală din suflete cere să fie pusă pe o temelie religioasă $\breve{21}^{21}$.

21 Constantin Cucoş, Educaţia religioasă. Conţinut şi forme de realizare, Bucureşti, Edit. Didactică şi Pedagogică, 1996, p. 8. 


\section{Consecințele crizei morale. Soluţionarea ei din punct de vedere creştin}

Persoana fără muncă devine un asistat pentru hrană, veşminte şi nevoi medicale. Ea riscă să se refugieze în consumarea de droguri, alcoolism, sau să se exprime prin violenţă şi delicvenţă. Sărăcia cea mai cruntă se caracterizează prin pasivitate, apatie, nehotărâre.

Controlul naşterilor, prin folosirea anticoncepţionalelor, sau prin planificările familiale, prin sterilizare sau prin alte mijloace, atinge intimitatea fiinţei umane. Copiii reprezintă pentru numeroşi părinţi asigurarea unei fericiri prezente şi veşnice. Ei reprezintă împlinirea poruncii date de Dumnezeu: „Creşteţi şi vă înmulţiţi şi stăpâniţi pământul". Se cuvine să enumerăm, în trecere, mulţimea de factori care au contribuit la slăbirea vieţii familiale moderne şi contemporane: la libertatea necontrolată a celibatarilor de sex masculin se adaugă, mai târziu, şi de sex feminin; cu concursul prostituţiei, al practicilor neomaltusianiste şi al avorturilor, căsătoria, privită din punct de vedere strict individualist, este puternic aşezată pe principiul sterilităţii sistematice şi găsind, pentru a se menţine sau desface, colaborarea avortului, a adulterului şi a divorţului. Toate aceste practici, toate aceste instituţii, nu sunt decât părţi conexe ale unui sistem complet coerent care ruinează familia din zilele noastre, din interior şi din exterior. Din interior, prin trădarea iubirii, iar din exterior, prin însuşirea modelelor străine. În unul şi acelaşi complex intră, mai aproape de noi, pornofilia, homosexualitatea şi pilula. De asemenea, toate acestea se constituie în nişte condiţii noi de viaţă. Astfel, ele ne apar drept coordonatele unei „noi civilizaţii”. Avem de a face cu principii şi concepţii, moduri de a fi şi de a se manifesta, susţinute de filozofia vremii, de ideologie, de literatură, mass-media, care contrazic flagrant concepţia creştină fidelă naturii imperativelor vieţii voite de Dumnezeu.

Cauzele sterilităţii sunt mai multe. Dacă există o sterilitate care apare ca o consecinţ̧ă a viciilor pe seama cărora s-a lăsat, şi care este pe deplin vinovată, există şi o alta, care nu poate fi condamnată. Anumite 


\section{$15^{\text {th }}$ International Symposium on Science, Theology and Arts}

căsnicii sterile, fără copii, nu sunt din cauza aceasta mai puţin onorabile decât cele fecunde şi de o valoare morală ireproşabilă.

Sterilitatea voluntară, care pune sub semnul întrebării însuşi sensul căsătoriei creștine, după una şi aceeaşi gândire religios morală, recrutează cupluri pe care le încadrează în mai multe categorii. Prima este formată din acei soţi pe care o boală venerică contractată înainte, în timpul sau după căsătorie îi face incapabili de a transmite viaţa; o altă categorie adună pe toţi aceea pe care pornirea spre desfrâu sau egoismul fără limită îi fixează în sterilitatea sistematică; în fine, ultima, şi cea mai numeroasă, cuprinde mulţimea imensă a însoţitorilor care îşi reduc la minimum numărul descendenţilor lor. Tertulian se exprimă în felul următor: „Homicidifestinatioprohiberenasci” (a împiedica naşterea înseamnă a te grăbi să ucizi). Copiii sunt darul lui Dumnezeu, tot omul are dreptul la viaţă ${ }^{22}$.

Pe fondul acestor stări de degenerare morală creşte criminalitatea, sănătatea tinerilor este ameninţată ( sida), piaţa de droguri cunoaşte o desfacere fără precedent ( canabasisul, afetaminele, opiul, cocaina, morfina, heroina), consumul lor a devenit o modă. În anul 1968 pe zidurile unei universităţi din Paris s-au scris următoarele cuvinte."este interzis să fie interzis". Această deviză reflectă foarte bine situaţia morală a societăţii actuale. Bucuria de a fi liber faţă de toate regulile, pentru a putea să-şi satisfacă toate dorinţele lor indiferent de natura lor : morală sau imorală ${ }^{23}$.

Pe acest fond se ajunge la instabilitatea politică, care duce la cursa înarmărilor, război: chimic, nuclear, ecologic, meteorologic, economic, secret, mediatic (presa, radioul, tv. şi cinematograful), prin dezinformare „războiul fără de arme”, difuzarea de documente false, cenzură- apărând numai a parte de adevăr- sau prin sondaje, prin care se formează opinii. Există şi un război al stelelor prin care cursa înarmărilor a atins cote astronomice, şi un război al pietrelor ( vezi ce se întâmplă aproape zilnic în conflictul dintre evrei şi palestinieni, mai nou, în România, între poliţie şi mieri).

\footnotetext{
${ }^{22}$ Citat la I. Moldovan, op. cit., p. 37, 39, 48.

${ }^{23}$ Pierre Lanares, op. cit., p. 106.
} 
Fuga de acasă, copiii nu trăiesc lângă părinţi, cel mai mult timp îl petrec singuri în faţa televizorului, (în SUA, la 50 de milioane de familii există 500.000 de copii care părăsesc familia)22, absenţa disciplinei familiale conduce la refuzul autorităţii şcolare, militare şi sociale. Ruptura de societatea adultă se exprimă prin haine, modul de viaţă, muzică, dans. De aici se ajunge la alcool, drog legal şi mortal şi la tutun, drog legal şi mortal cu urmări în domeniul sănătăţii : boli de cancer prin care sunt atinse căile respiratorii, cavitatea bucală, bronhiile, sistemul nervos, sistemul cardio-vascular, fertilitatea pentru femeile tinere ${ }^{24}$.

Există un decalaj între ţările sărace şi țările bogate. Nu există un corespondent între numărul locuitorilor dintr-o ţară săracă şi nivelul de trai dintr-o ţară bogată.

Tinerii de azi au nevoi de modele. Modelul suprem este Mântuitorul nostru Iisus Hristos. Poate nici când în istorie n-a fost chemată Biserica la o acţiune de o asemenea amploare şi profunzime. E chemarea lui Hristos la viaţă creştină, la verificarea ei în realitatea socială.

Concepţia creştină ne spune că toţi oamenii sunt egali, liberi şi fraţi, care trebuie să se iubească unii pe alţii, trăind în iubire şi frăţietate, conlucrând la realizarea unei vieţi fericite pentru toţi cei ce locuiesc pe pământ ${ }^{25}$.

Lactanţiu zicea undeva că „menirea virtuţii este de a nu păcătui” (omneigiturvirtutisofficium est non pecare). „A nu păcătui” este unul din corolarele acţiunii virtuţii în raport cu împărăţia negaţiei , atât de folosită de cei tineri, propovăduită în cultură şi filozofie de Eugen Ionescu, negaţie condusă de Satan. Calea vieţii trebuie căutată la fel ca drumul pe care-1 caută corăbiile pe mare : acestea din urmă rătăcesc pe căi nesigure dacă nu văd o lumină cerească după care să se călăuzească.

Misiunea formatoare a creştinismului, de reconstruire a personalităţii umane, devine idealul explicit al noii religii. Se urmăreşte

${ }^{24}$ Ibidem, p. 112.
${ }^{25}$ N. Mladin, op. cit., p. 155. 


\section{$15^{\text {th }}$ International Symposium on Science, Theology and Arts}

perfectarea în om a dimensiunii îndumnezeirii, ,„̂nomenirea” sa ; fizică şi sufletească, după ființa sa percepută din etern în cugetul creator al Raţiunii divine. (vezi Pr. prof. dr. D. Stăniloae, Teologia Dogmatică, vol.II, Bucureşti, 1978, p.59).

Cum vom putea să sporim pe Hristos în cugetul elevilor de liceu, este marea problemă asupra căreia Biserica, prin ierarhia ei , prin dascălii săi, prin membrii săi, trebuie să stăruie. Elevii de liceu învaţă prea puţin din tainele învăţăturii creştine. Când învăţăm doctrina Mântuitorului Hristos nu urmărim alte scopuri decât de a oferi pâinea noastră cea de toate zilele.

După o perioadă lungă de îndoctrinare din perspectiva unei singure concepţii - cea marxist-leninistă -, religia, ca şi celelalte forme de spiritualitate sau de compartiment, îşi revendică -pe drept - roluri şi funcţii care în regimul totalitar au fost forţat ocultate sau eludate. Pe de altă parte, criza de ordin moral al întregului corpus social reclamă şi obligă realizarea unei colaborări a instanţelor mai mult sau mai puţin specializate, în direcţia revitalizării moral-spirituale a poporului nostru. Iar între aceste instanţe, religia ocupă un loc aparte.

Biserica încetează de a mai fi un ,ghetou liturgic ${ }^{\text {26 }}$, ieşind cu demnitate pe arena socialului. Ea are de construit conştiinţe, suflete ; se cuvine ca ea să devină mai ofensivă, oferind alternative de viaţă, având iniţiative caritabile,(ceea ce a şi făcut, însă insuficient de cunoscute) implicându-se în multiple acţiuni culturale şi sociale ( La aceste cerinţe Biserica Ortodoxă Română poate să demonstreze cu cifre concludente că şi-a făcut datoria). Rămâne de actualitate îndemnul lui Emille Boutroux de la începutul secolului:

„Creştinismul trebuie negreşit să se adapteze la viaţa reală, dacă vrea să fie altceva decât un vis sublim şi efemer, dacă vrea să devină el însuşi o realitate. Şi viaţa reală conţine : grija existenţei ( mai ales felul acestei existenţe $n$. n.), a traiului bun şi a libertăţii exterioare, ştiinţa, filozofia, politica, artele, literatura, cultul religios, într-un cuvânt, toate

${ }^{26}$ C. Cucoş, op. cit., p. 107. 
manifestările naturale şi toate formele tradiţionale ale activităţii omeneşti" ${ }^{27}$.

\section{Bibliografie}

- $\quad$ Mladin,Dr.h.c, Nicolae, Studii de Teologie Morală, Sibiu, 1969.

- Moldovan,Pr. prof. dr, Ilie, Darul sfânt al vieţii şi combaterea păcatelor impotriva acestuia, Buc., 1997.

- Constantin Cucoş, Educaţia religioasă. Conţinut şi forme de realizare,București, 1996.

- $\quad$ Pierre Lanares, Faire face au desordre mondial, Trento, 1993.

- Coman,G. Pr. Prof. dr., Probleme de filosofie şi literatură patristică, Bucureşti, 1995.

- Colectiv de autori, Biserica şi problemele sociale, Bucureşti, 1933.

- Idem, Probleme actuale în Biserică şi Stat, Bucureşti, 1994.

- J. Lesourne, B.Lecomte, D'aprescommunisme, Paris, 1990.

- S. Milgram, Soumission a l'autorite, Paris, 1974.

${ }^{27}$ Citat la Ibidem. 